\title{
Decolonisation and Colonial
}

\section{Collections}

\section{An Unresolved Conflict}

\author{
JOS VAN BEURDEN
}

If decolonisation merely meant independence for a colony, it would lie in the distant past. Nowadays, however, decolonisation is considered to be an ongoing process and unresolved conflict. This forum highlights the migration of cultural and historical treasures to the metropoles during five centuries of European dominance and explores how to address it. Most former colonial powers in Europe, their museums and many historians have long trivialized this transfer. In November 2017, however, a European head of state announced that the return of disputed colonial objects to Africa would become a policy priority. Since 2013 Erfgoed Delft, the then cultural heritage department of the city of Delft, and the present National Museum of World Cultures have been involved in a large scale transfer of objects to Indonesia. In September 2017, the Rijksmuseum in Amsterdam launched a research project on the provenance of ten colonial objects. Some former source countries (e.g. China, Benin, Nigeria and Ethiopia) are active in the discussion about missing colonial collections. They are particularly eager to retrieve war booty. Other source countries are less involved. This forum shows that a discussion about the future of these treasures is far broader than the actual objects and their return. None of the contributors argues that returning tainted colonial collections is the only way to resolve this conflict, or that this issue is the only one that needs to be addressed. Instead, they present alternatives and discuss the complexities surrounding colonial objects and issues of return.

Als dekolonisatie niets anders zou betekenen dan de onafhankelijkheid van een kolonie, zou dit tot het verre verleden behoren. Tegenwoordig wordt dekolonisatie echter beschouwd als een doorlopend proces en een onopgelost conflict. Dit forum werpt licht op de migratie van culturele en historische schatten naar de metropolen gedurende vijf eeuwen Europese dominantie en onderzoekt de wijze waarop met 
deze problematiek moet worden omgegaan. Deze overgang is jarenlang gebagatelliseerd door de voormalige koloniale machten in Europa, de verschillende Europese musea en een groot aantal historici. In november 2017 kondigde een Europees staatshoofd aan dat de teruggave van omstreden koloniale objecten aan Afrika prioriteit zou krijgen. Sinds 2013 hebben Erfgoed Delft, de toenmalige cultuurafdeling van de gemeente Delft, en het huidige Nationaal Museum van Wereldculturen gewerkt aan een grootschalige repatriëring aan Indonesië. In september 2017, startte het Rijksmuseum in Amsterdam een onderzoek betreffende de herkomst van tien koloniale objecten. Een aantal landen van waaruit schatten werden weggehaald (zoals China, Benin, Nigeria en Ethiopië), is actief betrokken bij de discussie over koloniale collecties. Zij richten zich vooral op de teruggave van oorlogsbuit. Andere landen zijn minder betrokken. Dit forum laat zien dat een discussie over de toekomst van deze schatten veel verder gaat dan de objecten zelf en de teruggave ervan. In geen van de bijdragen wordt gesteld dat teruggave van de besmette koloniale collecties de enige oplossing is van dit conflict, of dat dit het enige probleem is dat besproken moet worden. In plaats daarvan worden in de volgende artikelen alternatieve oplossingen geboden en de complexe problemen met betrekking tot de koloniale objecten en teruggave bediscussieerd.

In her study Decolonising Methodologies, Maori scholar Linda Tuhiwai Smith argues that colonialism is not a 'finished business'. ${ }^{1}$ Although the rise of new states radically changed the world order, much of the colonial legacy persists, and many new states do not control their economic resources. Colonialism, as an expression of imperialism, 'still hurts, still destroys and is reforming itself constantly'. ${ }^{2}$ Decolonisation remains ongoing. Political philosophers such as Walter Mignolo from Argentina and Achille Mbembe from Cameroon confirm Smith's position. Mignolo emphasises the need to escape 'mental slavery (delinking)' as 'the way to escape coloniality'. ${ }^{3}$ Mbembe describes how the extensive immaterial and material damage of European colonialism has resulted in 'the forced break with the self', [...] 'expropriation', and 'humiliation' and explores how these conditions continue to affect Africans and other previously colonised peoples to this day. 4

Part of the decolonisation concerns our mind-set. Previously colonised peoples have 'to recover ourselves, to claim a space in which to develop a sense of authentic humanity', as Gloria Wekker writes. ${ }^{5}$ For descendants of the former colonisers, this self-recovery includes exploring blind spots, their

Research and Indigenous People (London 2012) 25.

2 Smith, Decolonising Methodologies, 20.

3 E-international relations, Interview: Walter Mignolo. Part 1: Activism and Trajectory, 17 January 2017, http://www.e-ir.info/2017/01/17/ interview-walter-mignolopart-1-activism-andtrajectory/. Accessed 10 April 2018.

4 Achille Mbembe, Kritiek van de zwarte rede (Amsterdam 2015) 117-118. English edition: Critique of Black Reason (Durham and London 2017).

5 Smith, Decolonising Methodologies, 24. 


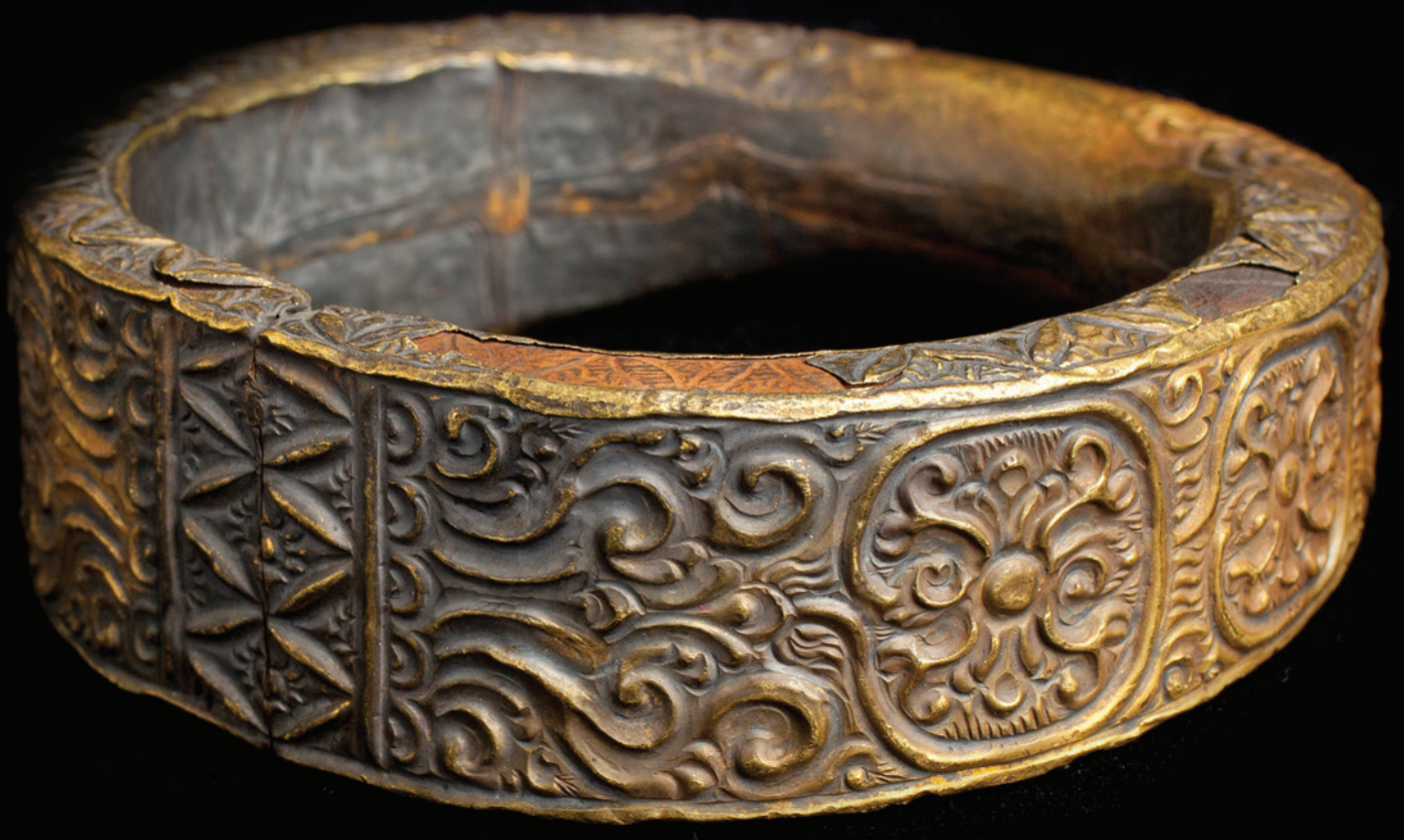

$\Delta$

Leg ring, example of war booty. It was part of the Lombok treasure, captured by Dutch soldiers in 1894. Collection National Museum of World Cultures, the Netherlands, RV-2364-87.

Photograph: National Museum of World Cultures. 
exceptionalism and the conviction that they are ethical and have something special to offer. ${ }^{6}$ A new mind-set is conducive to considering more critically the future of cultural and historical objects of which the shipment from colonial possessions to the metropoles has been disputed.

Does this appeal for further decolonisation mean that the writer of this contribution is subject to colonial determinism, that colonialism is a determining factor explaining all aspects of the situation? I am certainly aware of this risk and that, aside from the largely unidirectional flow of objects to the metropoles, a reverse, though considerably smaller flow took cultural objects from the metropoles to colonial possessions. Cultural gifts were exchanged as tokens of enforced loyalty inside Latin America, Asia and Africa outside the colonial framework. ${ }^{7}$ Powerful local rulers on these continents seized ample war booty upon defeating neighbouring rulers. The extent to which decolonisation has remained unresolved varies depending on the former colony and colonial power. Efforts are increasing to channel the debate about cultural heritage and bridge the gap between the two sides, ${ }^{8}$ while some approaches are more successful than others. ${ }^{9}$

Why then does the author focus on tainted colonial cultural objects such as war booty, objects confiscated by missionaries and others and stolen and smuggled items? The issue of disputed colonial collections has long been taboo and, as Couttenier argues in this forum, is still taboo in some countries in Europe. While both soft and hard law measures have been taken to deal with works of art confiscated by the Nazis and ongoing smuggling and theft of art and antiques, and the presence of colonial human remains in western collections has become less self-evident, general agreement has yet to be reached about the tainted colonial objects in Western collections.

While researchers have added to the general historiography on European colonialism in recent decades ${ }^{10}$, publications rarely address the frequently dubious provenance of colonial objects and acquisition practices among colonial officials, soldiers, missionaries, scholars and others. Restricting the research scope to Belgium, the DR Congo, Indonesia and the Netherlands reveals a few striking data. A neglected but important one is Congo-Tervuren:Allez Retour by Boris Wastiau. The staccato style of the book probably relates to the Royal Museum for Central Africa (Tervuren, Belgium)

\section{Colonialism and Race (Durham and London 2016) 5 .}

7 See e.g. Martijn Eickhoff and Marieke Bloembergen, 'Exchange and the Protection of Java's Antiquities: A Transnational Approach to the Problem of Heritage in Colonial Java', The Journal of Asian Studies, 72:4 (2013) 893-916.

8 See e.g. Susan Legêne, Bambang Purwanto and Henk Schulte Nordholt (eds.), Sites, Bodies and
Stories: Imagining Indonesian History (Singapore 2015).

9 See e.g. Jos van Beurden, Herplaatsing Nusantara collectie 2013-2018. Lessen voor de toekomst (Delft/ Leiden 2018) (forthcoming).

10 See e.g. publications of KITLV/Royal Netherlands Institute of Southeast Asian and Caribbean Studies, http://www.kitlv.nl/publications/. Accessed 15 February 2018. 


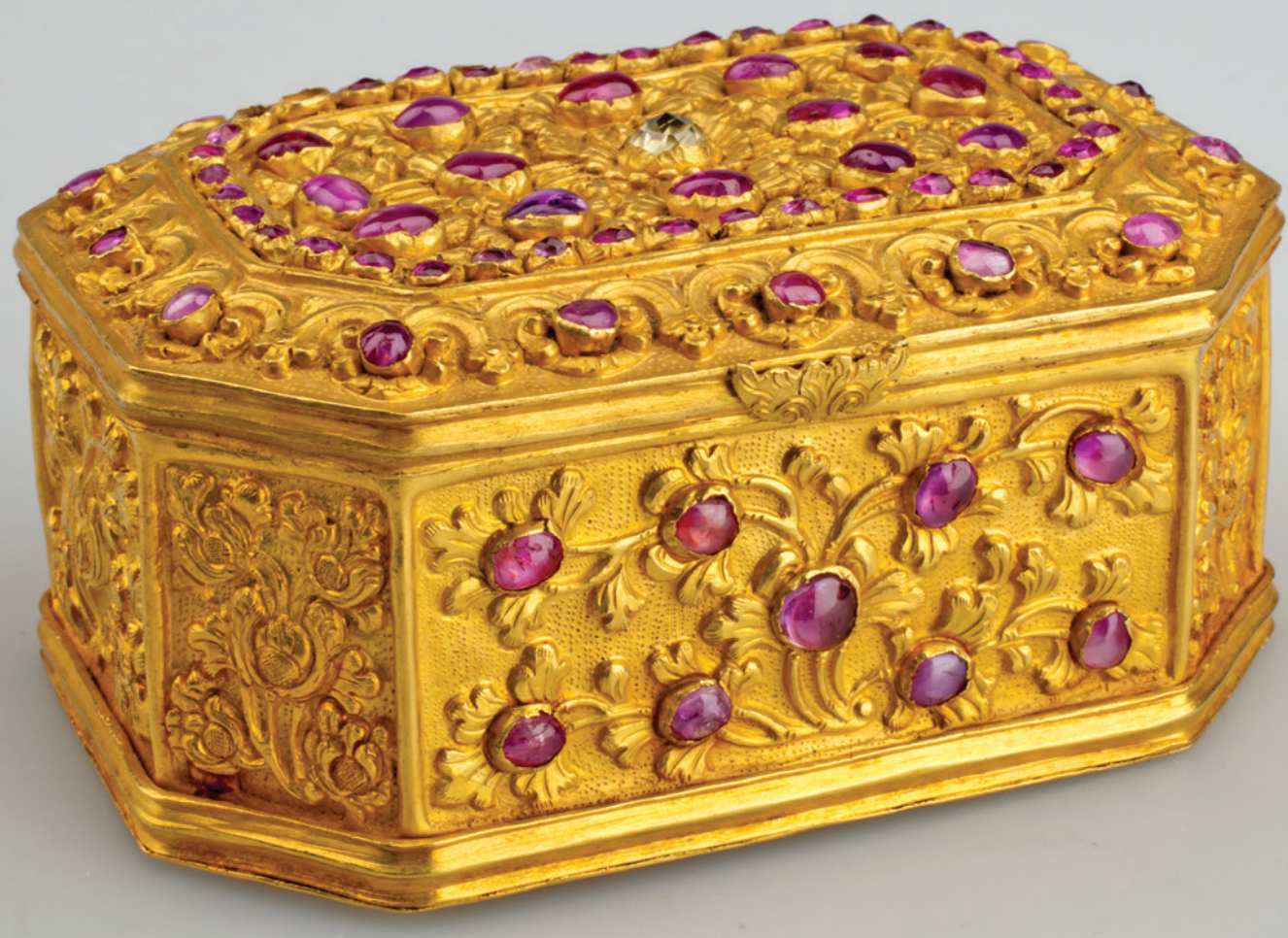

$\Delta$

Tobacco box with rubles and decorated with passionate flowers and leaf motifs, example of war booty. It was part of the Lombok treasure, captured by Dutch soldiers in 1894. Collection National Museum of World Cultures, the Netherlands, RV-4905-75.

Photograph: National Museum of World Cultures. 
where the author worked at the time. Wastiau lists the 114 objects returned from the museum repository to DR Congo in the 1970s. Although many had little or no cultural or historical value ${ }^{11}$, the DR Congo lacked experts to examine the items returned. More recently, in The Legacy of Collecting, Wastiau (by now director of the Musée d'ethnographie in Geneva) has qualified colonial collecting in Belgian Congo as violent and urges disclosing the provenance of colonial objects. ${ }^{12}$

In his study Congo tentoongesteld on Belgian anthropology between 1882 and 1925, historian and anthropologist Maarten Couttenier illustrates how colonial officials and military and amateur ethnographers acquired war booty for the museum in Tervuren. ${ }^{13}$ Around 1900 almost 40 percent of the Tervuren collection was catalogued as war-related. ${ }^{14}$ Historian Sarah van Beurden describes the dynamics in the negotiations about the return between Brussels and Kinshasa in the 1970s. Belgium and the museum in Tervuren denied the problematic provenance of many objects, while many in the Belgian government viewed the returning treasures as a way of safeguarding Belgian mineral interests in this colony. ${ }^{15}$ Most studies about Belgium and DR Congo are by Western scholars and museum professionals. Attributing the origin of these studies to 'the poor situation of historical research' in DR Congo, as Goddeeris and Kiangu have written, might not be a satisfactory explanation. ${ }^{16}$ Possibly Congolese researchers have other research priorities, while their European colleagues seek to come to terms with colonialism.

Likewise most studies about cultural ties between the Netherlands and post-independence Indonesia long came mainly from Western authors. My exchanges with colleagues in Indonesia suggest that issues such as how the Netherlands acquired cultural and historical objects during colonialism is a greater concern in the West than in the former colonies. The Netherlands and other countries in Europe have discovered the many questionable objects in our public and private collections. Such awareness did not exist shortly after Indonesian independence, as historian Caroline Drieënhuizen explains in her transfert de pièces ethnographiques du Musée royal de l'Afrique central à l'Institut des Musées nationaux du Zaïre 1976-1982 (Tervuren 2000) 15-58. Collecting in the Belgian Congo and the Duty of Unveiling Provenance', in: Paula Hamilton and James B. Gardner (eds.), The Oxford Handbook of Public History (Oxford 2017) 460-478.

13 Maarten Couttenier, Congo tentoongesteld. Een geschiedenis van de Belgische antropologie en het museum van Tervuren (1882-1925) (Leuven/ Voorburg 2005) 177.

Sarah Van Beurden, Authentically African: African Arts and Postcolonial Cultural Politics in Transnational Perspective (Congo [DRC], Belgium and the USA, 1955-1980) (Philadelphia, University of Pennsylvania, PhD thesis 2009) 136-137. Idesbald Goddeeris and Sindani E. Kiangu, 'Congomania in Academia. Recent Historical Research on the Belgian Colonial Past', BMGN Low Countries Historical Review 64:4 (2011) 67. 


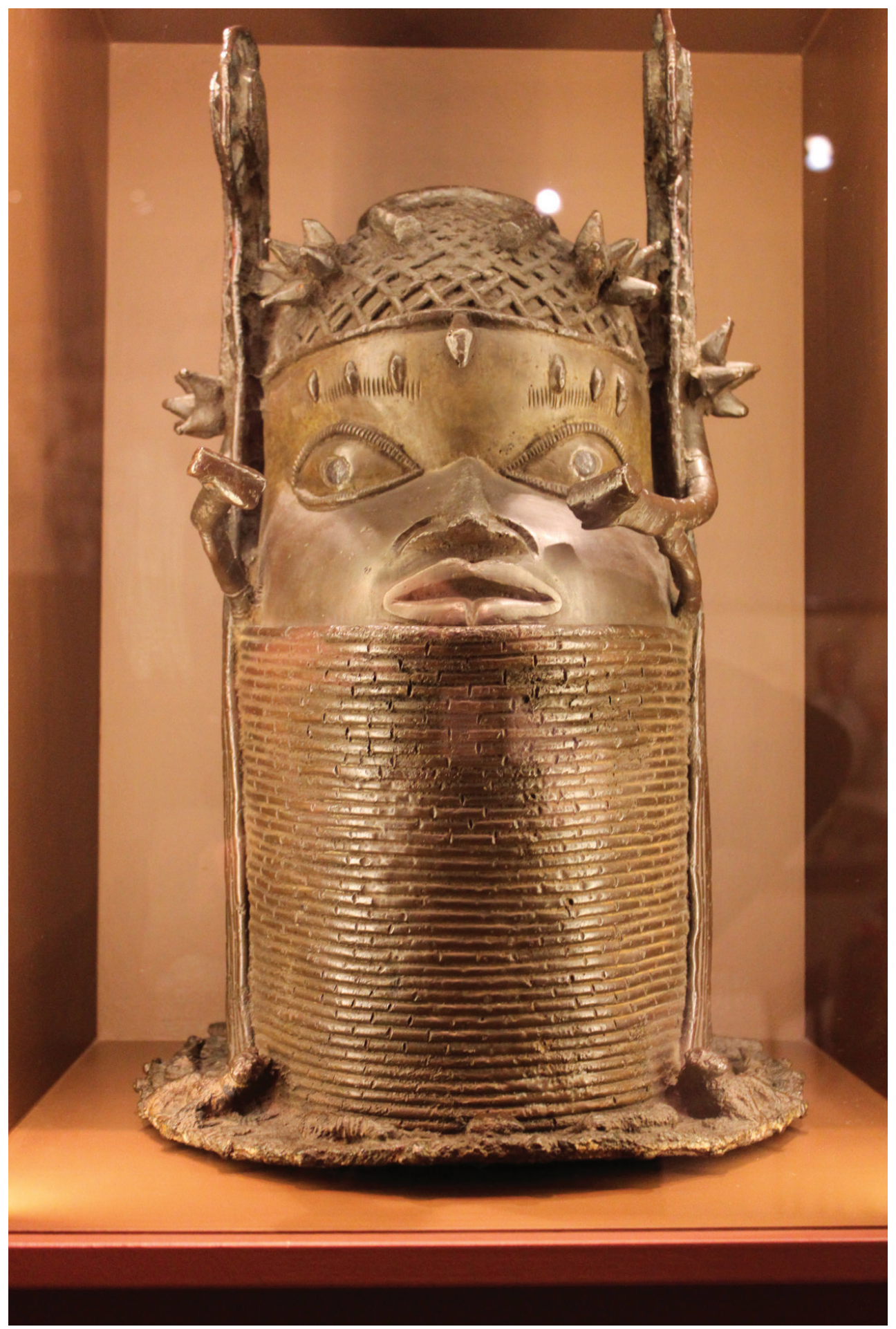

$\Delta$

Benin king (brass), example of war booty. It was captured by British soldiers in 1897.

Collection National Museum of World Cultures, the Netherlands, acquired in 1926, RV-2668-445.

Photograph: Jos van Beurden 
contribution to this forum, when ownership of colonial objects was disputed between the two countries.

In the 1990 publicist Ewald Vanvugt in his study of the Lombok war booty associated the nature of colonialism with acquisition practices. ${ }^{17}$ In her dissertation about elite European families in the Dutch East Indies, Drieënhuizen concludes that the objects in their collections reflect not only how they constructed their identities but also wars, conflicts, travel and other events. ${ }^{18}$ Describing the value of cultural artefacts and landscapes in his country from precolonial times until the present, archaeologist Tular Sudarmadi critiques the official heritage discourse during and after the colonial period, which neglected Islamic and indigenous cultures. ${ }^{19}$ This impacted the post-independence return negotiations with the Netherlands. In Indonesia: The Discovery of the Past, museum professionals Endang Hardiati and Pieter Ter Keurs and a hybrid group of authors offer information about the link between collecting and colonial subjugation. ${ }^{20}$ Harm Stevens has researched the acquisition history of objects in the collection at Amsterdam's Rijksmuseum, with which he is affiliated. Like Boris Wastiau, he faces unpleasant truths and raises the return issue. ${ }^{21}$

General studies about cultural relations between coloniser and colony and return issues are rare. In Treasures in Trusted Hands, I have started to chart the massive unidirectional flow of cultural and historical objects from colonial possessions to Europe and discuss ways to deal with this in the twenty-first century. I argue that their continued presence in Europe should not be taken for granted and that historians have a role to play. The pain and anguish, often caused by the involuntary loss of objects and the associated injustice, have largely remained below the radar and merit additional study on both sides. Couttenier refers to pain in his contribution to this Forum about a kitumba statue in DR Congo. Starting in the fifth century BC in Roofgoed, Ewald Vanvugt presents a chronological diatribe about objects and collections of questionable origin in European museums. 'Without overseas loot, Europe would not be rich,' he states. Half the acquisitions he mentions were made in the European colonial era. He does not explore the return issue. ${ }^{22}$ In The Return of Cultural

Ewald Vanvugt, De schatten van Lombok

Honderd jaar Nederlandse oorlogsbuit uit Indonesië (Amsterdam 1994).

Caroline Drieënhuizen, Koloniale collecties,

Nederlands aanzien. De Europese elite van Nederlands Indië belicht door haar verzamelingen, 1811-1957 (Amsterdam, University of Amsterdam, $\mathrm{PhD}$ thesis 2012) 325.

Tular Sudarmadi. Between Colonial Legacies and Grassroots Movements: Exploring Cultural Heritage Practice in the Ngadha and Manggarai Region of 
Treasures Jeannette Greenfield analyses suspicious acquisitions and return claims regarding a great many objects and collections. ${ }^{23}$

Some developments indicate a change in mind-set towards tainted colonial objects in countries in Europe. In 2010 the cultural authorities of Nigeria and representatives of the Edo Kingdom embarked on a dialogue with some Western museums about the future of the Benin objects, and the two sides started to work together. British soldiers had seized the objects during a raid in 1897 . Despite some progress, no Benin objects have found their way back to Nigeria yet, be it on loan or as a return.

From October 2016 until May 1017, the exhibition 'German colonialism: Fragments, pasts and present' at the Deutsches Historisches Museum in Berlin showcased, amongst others, colonial objects taken from Namibia and China around $1900 .{ }^{24}$ Major institutions in Berlin, Dresden and other German cities holding collections of colonial remains and relics are cooperating with former German colonial possessions in Africa and the Pacific to repatriate these items. ${ }^{25}$

In August 2016 the government of Benin, with help from unESCO, officially demanded that France return some five thousand objects that had disappeared during the colonial period. ${ }^{26}$ Public museums in the West African state together hold 4,50o objects, while the Musée du quai Branly in Paris alone has more than 5,500 items. ${ }^{27}$ Benin qualifies many of the objects in the claim as war booty, seized by the French army from the last King of Dahomey (Béhanzin) in 1892. Hélène Le Gal, the Africa advisor to former President Hollande, was quoted in the French media as asserting that King Béhanzin, on the verge of his deportation to the Caribbean isle of Martinique, had 'voluntarily' surrendered his throne, sceptre and sculptures of his father and grandfather to the French General Dodds. ${ }^{28}$

Sacre
Jeanette Greenfield, The Return of Cultural

Treasures (Cambridge 2007).

Deutsches Historisches Museum, German

Colonialism: Fragments Past and Present (Berlin 2016).

Berlin Postkolonial, 'Prussian Colonial Heritage:

Sacred Objects and Human Remains in Berlin

Museums', http://www.berlin-postkolonial.de/

cms/index.php/9-news/kurzmeldungen/127-

conference-prussian-colonial-heritage. Accessed

14 November 2017; Staatlichen Kunstsammlungen

Dresden, 'Freistaat Sachsen gibt menschliche

Gebeine aus Museum für Völkerkunde Dresden

an Hawaii zurück,' 23 October 2017, https://www.

skd.museum/presse/2017/freistaat-sachsen-

gibt-menschliche-gebeine-aus-museum-fuer- voelkerkunde-dresden-an-hawaii-zurueck/.

Accessed 14 November 2017.

26 'Trésors pillés : "La France doit répondre positivement à la demande du Bénin"', Le Monde, 1 August 2016, http://www.lemonde.fr/afrique/ article/2016/08/01/tresors-pilles-la-france-doitrepondre-positivement-a-la-demande-dubenin_4977095_3212.html. Accessed g November 2017.

27 Patrick Effiboley, 'Les musées béninois: du musée ethnographique au musée d'histoire sociale', French Studies in Southern Africa 44 (Gauteng 2015) 30-61, 48.

28 'Bénin Des trésors culturels loin du pays natal', L'Humanité, 12 August 2016, https://www. humanite.fr/benin-des-tresors-culturels-loin- 
French President Emmanuel Macron must have had this claim in mind, when he told students in Ouagadougou (Burkina Faso) on 28 November 2017 that much of the cultural heritage from several African countries being in France was unacceptable. Finding ways to return these items temporarily or permanently became a new priority in his policy. ${ }^{29}$ Soon afterwards, concerned diaspora organisations, scholars and prominent citizens in Germany requested Chancellor Angela Merkel in an open letter to disclose her position on Macron's announcement. ${ }^{30}$ In response to the French President and the open letter, Hermann Parzinger, President of the powerful Prussian Culture Foundation, called for an international conference and for principles and guidelines to deal with colonial collections. In his view, the issue had become too complicated to address at a national level. Moreover, provenance research conducted in cooperation with researchers from the former colonies is more effective. ${ }^{31}$ The German government will fund four academics for researching colonial objects of the Prussian Culture Foundation.

The recent offer from the Victoria and Albert Museum in London to transfer the Maqdala exhibits on a long-term loan to Ethiopia aligns with this new position. The museum worked closely with the Ethiopian community, the Ethiopian embassy and the Ethiopian Orthodox Church in London. In 1868, hundreds of treasures had ended up in Great Britain after the British army defeated Ethiopian Emperor Tewodros and seized his arms, a crown, royal garments and other valuables from his palace and ancient manuscripts and ritual objects from nearby churches in Maqdala in the centre of the country. It is unclear whether the director of the Victoria \& Albert museum made the promise of such a loan too spontaneously. The government in Addis Ababa and Ethiopia's ambassador in London disagree about it. ${ }^{32}$

du-pays-natal-613708. Accessed 7 November 2017. Also: Corinne Herskovitch and Didier Rykner, La restitution des oeuvres d'art (Paris 2011) 77. The Missiemuseum Steyl in the Netherlands also holds war booty from King Béhanzin.

'Emmanuel Macron promet à l’Afrique des restitutions des œuvres africains "d'ici a 5 ans", La Croix, Montrouge Cedex, 28 November 2017, https://www.la-croix.com/Culture/ Expositions/Emmanuel-Macron-prometIAfrique-restitutions-doeuvres-africaines-dici-5ans-2017-11-28-1200895496. Accessed 5 February 2018. von afrikanischen Gebeinen und Kulturobjekten', open letter to Bundeskanzlerin Dr. Angela Merkel, 18 December 2017, http://www.berlinpostkolonial.de/cms/index.php/initiativen/9news/kurzmeldungen/128-offener-brief-anmerkel. Accessed 5 February 2018.

31 Hermann Parzinger, 'Bauen wir Museen in Afrika!', Frankfurter Allgemeine Zeitung, 25 January 2018, http://www.faz.net/aktuell/feuilleton/ debatten/kunst-der-kolonialzeit-bauen-wirmuseen-in-afrika-15415223.html. Accessed 21 February 2018. Tristram Hunt, Maqdala 1868, http://www.vam. ac.uk/blog/network/maqdala-1868 and https:// www.facebook.com/BBCnewsAfrica/videos/ vb.285361880228/10156485974305229/?type $=$ 2\&theater. Accessed 12 April 2018. 
Similar change is getting under way in the Netherlands as well. Since 2013 the municipal authorities of Delft, the National Museum of World Cultures and the Museum Nasional Indonesia in Jakarta have been discussing the return of part of the collection from the former Museum Nusantara in Delft to Indonesia. The offer was made after 20 percent of the collection was set aside as 'worth protecting': this section had to remain available to the public in the Netherlands. The Southeast Asian country accepted only ten percent of the remaining objects. ${ }^{33}$ For a number of years the National Museum of World Cultures has been developing a repatriation policy. The Rijksmuseum in Amsterdam has announced a study on the provenance of ten colonial objects, including possible return to their country of origin. ${ }^{34}$

Other developments indicate that the debate about the future of colonial collections has stopped. When the authorities of Benin stated the claim mentioned above, Julien Volper of the Royal Museum for Central Africa in Tervuren expressed a passionate appeal in the French daily Le Figaro to 'defend' such collections against the 'enemy' in Africa and Europe trying to 'turn' museums in Europe into 'a graveyard' by 'emptying' them. ${ }^{35}$ In his view, the claim arose from biased ideas about European guilt regarding their allegedly racist and reactionary past. A recent study, also edited by Volper, on a Congo collection of Belgian Jesuits at the Royal Museum for Central Africa comprises largely truncated accounts of the objects, traces the Europeans who acquired them, mentions in some cases how they obtained them but overlooks the possible anguish of users deprived of their possessions. ${ }^{36}$

In the British Museum the presentation of colonial objects reflects gaps. In A History of the World in 100 Objects, Neil MacGregor, the museum director until 2015, omits information about acquisition practices and claims by former colonies. On an ancient gilt bronze statue of Tārā from Sri Lanka: 'nothing is known about how and when the statue was found nor how it came [...] in the possession' of the London museum. ${ }^{37}$ Jeannette Greenfield, however, had previously written in her authoritative study The Return of Cultural Treasures that Governor Robert Brownrigg of Ceylon had presented the statue to the British Museum in 1830 and that the Sri Lankan government had claimed it in 1980 , as it was considered war booty. ${ }^{38}$ MacGregor's book

Over de toekomst van koloniale culturele objecten', Museumpeil 48 (2017) 20-22. daar vaar ik op', https://www.nrc.nl/ nieuws/2017/og/22/schaamte-is-mijn-kompasdaar-vaar-ik-op-13117614-a1574533. Accessed 14 October 2017.

Julien Volper, 'Défendons nos musées!', Le Figaro, 14 September 2017, http://www. lefigaro.fr/vox/societe/2017/09/06/3100320170906ARTFIGo0343-defendons-nos-musees. php. Accessed 26 September 2017.

36 In: Julien Volper (ed.), Giant Masks from the Cong: A Belgian Jesuit Ethnographic Heritage (Tervuren 2015) 93, 95 .

37 Neil MacGregor, A History of the World in 100 Objects (London 2012) 298.

38 Jeanette Greenfield, The Return of Cultural Treasures (Cambridge 2007 [1989]) 133-134. 
does not examine the problematic origin of objects collected by Lieutenant General Thomas Raffles on Java in the early nineteenth century. Long before this book appeared, historian Peter Carey revealed how Raffles looted the kraton (palace) of the Sultan of Yogyakarta in 1812 and took krisses, other weapons and gold ornaments from the Sultan and his relatives. ${ }^{39}$ In Displaying Loot: The Benin Objects and the British Museum, Swedish archaeologist Staffan Lundén finds that since it opened in 1783, the British Museum has maintained a 'retentionist' dogma, which implies that retention is always a good thing and return a bad thing. ${ }^{40}$ The museum continues to distinguish a normal, individual, rational, developed and developing Western self from a different, collective and traditional non-Western other.

The retentionist perspective of scholars as Volper and MacGregor corresponds with the 2002 Declaration on the Importance and Value of Universal Museums, ${ }^{41}$ in which directors of leading museums in the West (including those of important museums in the United States, the Louvre, the State Museums in Berlin, the Hermitage in St. Petersburg, the Rijksmuseum in Amsterdam and the British Museum in London) designated these institutions as universal. Objects acquired in the past had to be reconciled with changes in sensitivities and values. They tried to conclude the debate about questionable provenances on that note and agreed to act more ethically when acquiring new objects. The statements by President Macron, the Prussian Culture Foundation and the Rijksmuseum clearly deviate from this Declaration from 2002.

The above makes clear that the debate about the decolonisation of colonial collections is now permanently embedded in the discussion about European colonialism. Again, however, decolonisation and return are not identical. Decolonisation means that former colonies, their museums and others holding colonial objects of great historical and cultural importance conduct serious research on the provenance of these objects, preferably in cooperation with colleagues from the former colonies. They are to publish the findings and enter a dialogue with the former colonies concerned about the future of these important treasures. Together, the two sides can decide where an object is best placed.

In this new mission, the task of historians is twofold. First, historical research on colonialism is to be linked with studying the provenance of colonial objects. Historians control the tools to find this information and can help those holding important cultural and historical objects complete the accounts of these objects. The second task is to become more vocal in the public debate and to help explore and expose this aspect of decolonisation. One restriction is that decisions about the future of tainted colonial objects Dipanagara and the End of an Old Order in Java, 1785-1855 (Leiden 2008) 334, 341.
(Gothenburg, Gothenburg University, PhD thesis 2016) 22.

41 In: Lyndel Prott (ed.) Witnesses to History: Documents and Writings on the Return of Cultural Objects (Paris 2009) 116-118. 
are taken not by historians but by the stakeholders: museums, government bodies, communities of origin, descendants of former local rulers and private holders with strong ties to the objects at issue.

The contributions to this forum further performing these tasks and reveal the complexities of the debate about return issues and histories of objects. The focus in this introduction has been on the decolonisation of colonial collections as primarily a European problem and the extension of this debate in Europe to the political and public domains. The other contributions reveal other complexities. In ‘EO.o.o.7943’ Maarten Couttenier explains the importance of research on objects in the countries of origin. He takes readers on a journey to a rural area in DR Congo, where a Belgian trader confiscated a kitumba statue late in the nineteenth century and reveals claims from different actors in different periods. In ‘Mirrors of Time and Agents of Action' Caroline Drieënhuizen describes research on Indonesia and the Netherlands and selects three contested objects to illustrate how such items reflected and furthered decolonisation and nationalist policies in both countries in the 1970s. In her view the discussion about colonial cultural objects predominantly concerns the meanings of objects and the underlying domination structures. In 'Decolonising the Aceh Museum: Objects, Histories and the Narratives' Ajeng Arainikasih and Hafnidar share their research on Aceh. In the Netherlands, decolonising colonial collections entails confronting the dark sides of Dutch colonial history. In Indonesia, the process means dealing with colonial and anticolonial mind-sets and telling stories from the perspective of people and society, rather than that of the state.

Dr Jos van Beurden (1946) is a researcher affiliated with the Vrije Universiteit Amsterdam and a fellow at the Africa Studies Centre Community of Leiden University. Since the early 1990 s he has studied the protection of and illicit trade in art and antiquities of vulnerable countries. Based on trips to these countries and research, Van Beurden did radio features and wrote general articles, followed by academic articles. He has co-founded international networks in this field. In 2001 he published Goden, graven en grenzen. Over kunstroof uit Afrika, Azië en Latijns Amerika (Gods, graves and frontiers: About art theft from Africa, Asia and Latin America) and included incidents in the port of Rotterdam, when customs officials discovered stolen or smuggled art objects from West Africa and Southeast Asia. In The Return of Cultural and Historical Treasures: The Case of the Netherlands (2012) Van Beurden describes 34 instances of objects returned by the state and public institutions of the Netherlands. Eleven concerned colonial objects. Since these returns had taken place in the 1970s and 1980s, he concluded that the discussion about such objects had come to a standstill. In 2016 Van Beurden defended his PhD thesis at the Vrije Universiteit about restitution issues, comparing the dealing with Nazi looted art with dealing with colonial cultural and historical objects. A revised version of his PhD thesis was published as Treasures in Trusted Hands: Negotiating the Future of Colonial Cultural Objects (Leiden, 2017). Email: jos.vanbeurden@inter.nl.net, www.josvanbeurden.nl. 